\title{
Simulation and Techno-Economic Analysis of On- Grid Battery Energy Storage Systems in Indonesia
}

\author{
$1^{\text {st }}$ Agus Ramelan \\ Dept. Electrical Engineering \\ Universitas Sebelas Maret \\ Surakarta, Indonesia \\ agusramelan@staff.uns.ac.id \\ $4^{\text {th }}$ Muhammad Hamka Ibrahim \\ Dept. Electrical Engineering \\ Universitas Sebelas Maret \\ Surakarta, Indonesia \\ hamka@staff.uns.ac.id
}

\author{
$2^{\text {nd }}$ Feri Ardriyanto \\ Dept. Electrical Engineering \\ Universitas Sebelas Maret \\ Surakarta, Indonesia \\ feri.adriyanto@staff.uns.ac.id \\ $5^{\text {th }}$ Irwan Iftadi \\ Dept. Industrial Engineering \\ Universitas Sebelas Maret \\ Surakarta, Indonesia \\ iftadi@gmail.com
}

\author{
$3^{\text {rd }}$ Chico Hermanu Brillianto Apribowo \\ Dept. Electrical Engineering \\ Universitas Sebelas Maret \\ Surakarta, Indonesia \\ chico@ft.uns.ac.id \\ $6^{\text {th }}$ Gilang Satria Ajie \\ Dept. Electrical Engineering \\ Universitas Sebelas Maret \\ Surakarta, Indonesia \\ satriagilang80@gmail.com
}

\begin{abstract}
The limited capacity of renewable energy sources in the grid utility is a challenge. Increasing the capacity of renewable energy sources is supported by energy storage in the grid. The Battery Energy Storage System (BESS) allows storing more electricity from New and Renewable Energy (EBT) sources to meet load requirements. This paper designs a technoeconomic study of various battery technologies using HOMER (Hybrid Optimization Modeling Software) software simulation. Simulations are made for grid-connected photovoltaic systems in Indonesia. HOMER is used to find the energy cost $(\$ / \mathrm{kWh})$ for each type of battery technology and battery system size. The simulation is designed using $1 \mathrm{MWp} P V$ component parameters, inverter, energy storage to be compared, residental load, and connected to the grid. The results will help to determine which technology and battery size is more suitable for the system. The findings from this paper resulted in the lowest Levelized Cost of Energy (LCOE) of \$ 1.03 in solar power generation.
\end{abstract}

Keyword- battery, energy Storage, on-grid photovoltaic, techno-economic

\section{INTRODUCTION}

Fossil fuels environmental impact, energy supply capacity, and energy grid resilience are major problems of the use of the grid system nowadays. An energy storage solution is needed to solve the problem. Energy storage can help supply energy from solar power stored in batteries, respond quickly to large demand fluctuations, make the grid more responsive, and reduce the need to build backup power plants. The effectiveness of an energy storage facility is determined by how quickly it can react to load changes, efficiency in the storage process, overall energy storage capacity, and charging speed [1].

PV Solar was the best installed technology in 2017, contributing for nearly $55 \%$ of renewable power capacity newly installed in 2017 [2]. Indonesia, which is located in the equatorial region, has a solar power plant (PLTS). It uses solar radiation as an energy source, which is the most promising potential, which is around $4.8 \mathrm{KWh} / \mathrm{m}^{2}$ or equivalent to $112,000 \mathrm{GWp}$. Even up to 2030, the International Renewable Energy Agency (IRENA), in its report on the global roadmap program for Renewable Energy Future (REmap) 2017, prospects that Indonesia has $47 \mathrm{GW}$ of solar power potential. Apart from being environmentally friendly, free energy sources, and easy installation, the construction of PLTS can increase the electrification ratio of rural and island areas as well as the NRE mix target by $23 \%$ by 2025 [3].
BESS allows EBT sources to be integrated into the network to save excess energy that is not needed at certain times and it is used at other times. This paper offers a study to optimize the size of the battery that will store energy from solar power systems in Indonesia. The use of battery allows efficient integration of solar energy with the utility grid at a lower cost and allows an increase in the overall share of electricity from the EBT source. Power plants will benefit more when using battery with PV on-grid systems as it allows for more energy saving and sales. As a result of all the points mentioned above, using battery with PV on-grid system is mutually beneficial for the government, private sector, and the state [4].

\section{LITERATURE REVIEW}

\section{A. New and Renewable Energy Battery System}

Battery storage is one of several technological options that can increase the flexibility of a power system and allow integration with renewable energy sources. Interconnected power systems can safely and reliably integrate renewable energy through energy storage[5]. Integrating appropriate renewable energy with grid-scale battery storage depends on the specific characteristics of the system, including:

a) Capital energy installation costs $(\$ / \mathrm{kWh})$.

b) A mix of generation technologies

c) Flexibility in generation sources

d) Interconnection with neighboring power systems

e) An hourly, daily, and seasonal profile of electricity demand

f) EBT sources profile

The DOE Global Energy Storage Database records each project intended to provide further insights. Figure 1 illustrates the frequency of all services appear in the database[6]. Services such as time shift of electrical energy, can also be linked to renewable energy. Renewable energy is clearly important in attracting the spread of energy storage in this period. The existence of energy storage has a very significant impact on the quality of the electricity grid. 


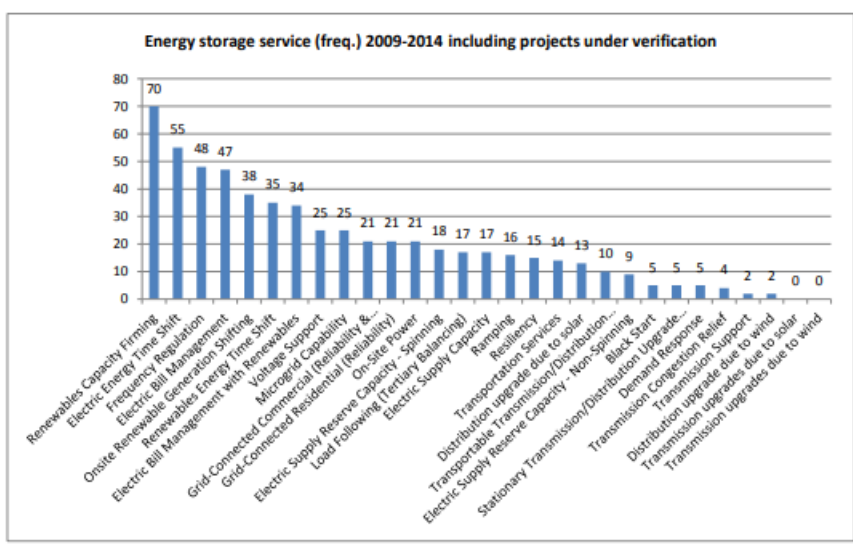

Figure 1 Single Energy Storage Service by Project, 2009-2014 [6]

The determination of the BESS location has important implications for the services that can be provided by the system. The most appropriate location for BESS will depend on the case use. In most cases, BESS will technically be able to provide a wide range of services. Therefore, when determining storage locations, it is important to analyze the costs and benefits of multiple locations to determine the optimal placement to fulfil system requirements.

\section{B. Battery Technology Parameter}

Energy storage is used for power system network support. The megawatt and kilowatt scale energy storage systems listed here have potential impacts in several areas, including transmission network and substation support, peak shaving, capital, reliability, and frequency regulation [7]

TABle 1. DifFerences Of BATtery TeChNology PaRAMETERs [7]

\begin{tabular}{|c|c|c|c|c|c|}
\hline $\begin{array}{c}\text { Technolo } \\
\text { gy }\end{array}$ & $\begin{array}{c}\text { Capacity } \\
\text { (MW) }\end{array}$ & $\begin{array}{c}\text { Powe } \\
\mathbf{r} \\
(\mathbf{M W})\end{array}$ & 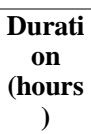 & $\begin{array}{c}\% \\
\text { Efficienc } \\
\text { y(Cycle } \\
\text { Total })\end{array}$ & $\begin{array}{c}\text { Cost } \\
\text { Total } \\
(\$ / k W h \\
)\end{array}$ \\
\hline CAES & 250 & 50 & 5 & $(>10,000)$ & $\begin{array}{l}1950- \\
2150\end{array}$ \\
\hline Pb-acid & $3.2-48$ & $1-12$ & $3.2-4$ & $\begin{array}{c}75-90 \\
(45000)\end{array}$ & $\begin{array}{c}2000- \\
4600\end{array}$ \\
\hline $\mathrm{Na} / \mathrm{S}$ & 7.2 & 1 & 7.2 & $\begin{array}{c}75 \\
(4500)\end{array}$ & $\begin{array}{c}3200- \\
4000\end{array}$ \\
\hline $\begin{array}{l}\mathrm{Zn} / \mathrm{Br} \\
\text { flow }\end{array}$ & $5-50$ & $1-10$ & 5 & $\begin{array}{c}60-65 \\
(10,000)\end{array}$ & $\begin{array}{l}1670- \\
2015\end{array}$ \\
\hline $\begin{array}{l}\text { V redox / } \\
\text { VRFB }\end{array}$ & $4-40$ & $1-10$ & 4 & $\begin{array}{c}65-70 \\
(13,000)\end{array}$ & $\begin{array}{l}3000- \\
3310\end{array}$ \\
\hline $\begin{array}{l}\mathrm{Fe} / \mathrm{Cr} \\
\text { flow }\end{array}$ & 4 & 1 & 4 & $\begin{array}{c}75 \\
(>10000)\end{array}$ & $\begin{array}{c}1200- \\
1600\end{array}$ \\
\hline Zn/air & 5.4 & 1 & 5.4 & $\begin{array}{c}75 \\
(4500)\end{array}$ & $\begin{array}{c}1750- \\
1900\end{array}$ \\
\hline Li-ion & $4-24$ & $1-10$ & $2-4$ & $\begin{array}{l}90-94 \\
(4500)\end{array}$ & $\begin{array}{c}1800- \\
4100\end{array}$ \\
\hline
\end{tabular}

The battery technology for the design in this paper is shown in Table 1, which explains the comparison between the types of batteries. Battery is one of the energy storage which is very suitable to be applied together with PV on-grid systems. As shown in Table 1, the highest efficiency is Lithium-ion (Li-ion) battery which can reach up to $97 \%$. VRFB has the highest number of cycles reaching 13,000, but has low efficiency. $\mathrm{ZnBr}$ has a high duration of up to 5 hours after $\mathrm{Na} / \mathrm{S}$ and $\mathrm{Zn} /$ water. The highest total investment cost is $\mathrm{Na} / \mathrm{S}$, besides that, VRFB is in the second position reaching $3,000 \$ / \mathrm{kWh}$.

Variations among battery parameters, especially efficiency, life cycle, and cost are shown in Table 1, but do not provide sufficient information to judge which technology is suitable for implementation with solar power (PV) generation. The battery allows storing excess electricity production during the day and can be used to serve the load at night. One of the best financial ways to compare BESS technologies is the cost of energy to be supplied across the system, defined as the Levelized Cost of Energy (LCOE) [4].

Of the seven battery technologies in Table 1 , the simulation data parameters for on-grid battery energy storage system in Indonesia are applied as a simulation data parameter using HOMER Pro. VRFB, $\mathrm{ZnBr}$, and Li-Ion technologies are the main focus of this paper. These three battery technologies will be simulated using HOMER Pro to find the LCOE for each technology and each battery system size:

a) The cost of installing capital energy $(\$ / \mathrm{kWh})$.

b) Replacement Cost $(\$ / \mathrm{kWh})$

c) O\&M Cost $(\$ / \mathrm{kWh})$.

d) Lifetime.

e) Minimum cost status

\section{Techno-economic Design with HOMER Simulation}

HOMER defines average energy cost (COE) as the average cost per kWh of useful electrical energy produced by the system. Levelized Cost of Energy (LCOE) is a parameter used to reveal the differences between several energy stores with the techno-economic analysis discussed in this paper. To calculate COE, HOMER divides the annual electricity production cost by the total electricity load served, using the following equation:

$$
C O E=\frac{C_{\text {ann,tot }}-C_{\text {boiler }} H_{\text {served }}}{E_{\text {served }}}
$$

where:

$C_{\text {ann,tot }}=$ the system total annual cost [\$/year]

$C_{\text {boiler }}=$ marginal boiler cost $[\$ / \mathrm{kWh}]$

$H_{\text {served }}=$ total thermal load served $[\mathrm{kWh} /$ year $]$

$E_{\text {served }}=$ total electricity load served [kWh/year]

\section{Methodology}

The Homer Pro is released by the National Energy Renewable Energy Laboratory (NREL), a national laboratory in the United States. The HOMER program used in this work is (Homer Pro 3.12.5). HOMER Pro is mainly used for technoeconomic design and evaluation for various hybrid power systems including renewable energy. HOMER Pro is able to create simulations for hybrid systems, consisting of nine variation components such as PV, wind, storage, hydro, 
biomass, heat and power combination, grid, load, hydrogen, and others.

The combined design of PV with energy storage using HOMER is focused on providing deliverable energy (i.e., energy on demand) and reliable capacity (i.e., network stability) with regard to the techno-economy of energy storage systems[8]. The combined system design consisting of PV, Inverter, Energy Storage, and connected to the grid is shown in the single line diagram in Figure 2 which consists of PV, inverter, BESS, and grid.

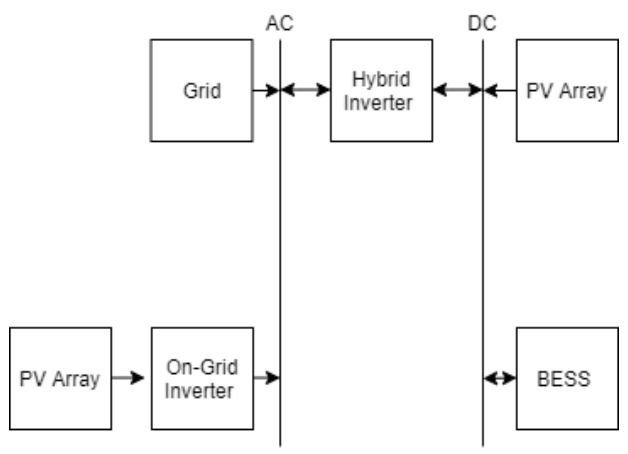

Figure 2 Single Line Diagram (SLD) Design

As a first step in using the HOMER Pro software, the PV system resource database of the required PV system must be determined. In the case adopted in this paper, the components of the energy source of solar radiation and temperature are located in the city of Surakarta, Central Java, Indonesia. Data taken from NASA Surface meteorology and Solar Energy is shown in Figure 3.

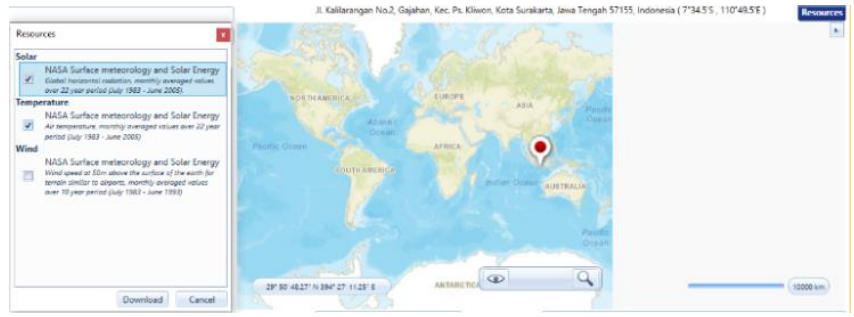

Figure 3 Defining resources in HOMER Pro

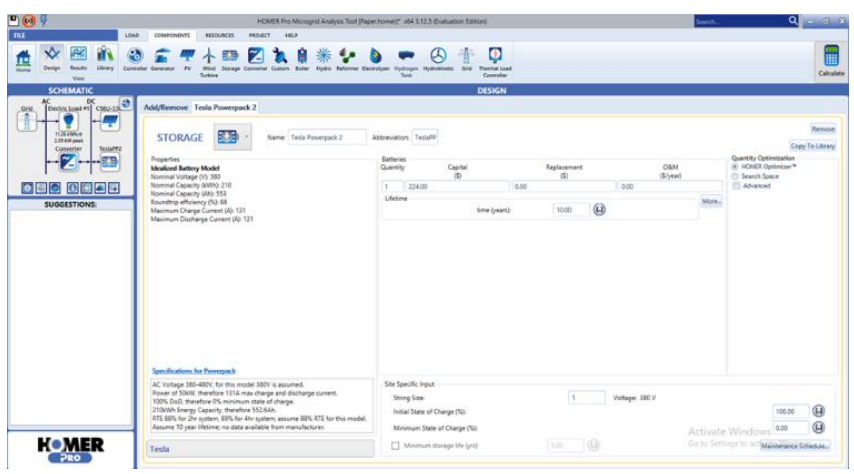

Figure 4 The example of PV On-Grid Energy Storage System

Figure 4 illustrates the choice of resources for a particular location. There are temperature, radiation, and wind speed. After defining the resources, the components needed in the system design are parameters on all components according to the real case. The parameters required for a PV system are system capacity, capital investment, service life, operation and maintenance costs which are shown in Figure 4. HOMER Pro is used to find the energy cost $(\$ / \mathrm{kWh})$ for each type of battery technology and battery system size. The results will help to conclude what technology and battery size would be more viable for PV on-grid system. The parameters for each component in the system design including grid, inverter, load, $\mathrm{PV}$, and BESS are described as follows.

\section{A. PV System Cost}

The economical input for the PV system is shown in Table 2. Parameters in the simulation (HOMER), the size of the PV system is $1 \mathrm{MWp}$.

TABLE I. PV PARAMETER

\begin{tabular}{clc}
\hline Parameter & Unit & Value \\
\hline Investment & $\$ / \mathrm{kWh}$ & 1,200 \\
\hline O\&M cost & \$/year & 20 \\
\hline Lifetime & Year & 2
\end{tabular}

\section{B. Inverter Cost}

TABLE II. INVERTER PARAMETER

\begin{tabular}{lll}
\hline Parameter & Unit & Value \\
\hline Investment & $\$ / \mathrm{kWh}$ & 90 \\
\hline Lifetime & Year & 25
\end{tabular}

\section{Grid}

The grid component is required for PV on-grid systems. However, no energy will be bought off the grid as this paper discusses the energy costs of a PV system combined with a battery.

\section{Load}

The load is inputted with a minimum value totaling 11.26 $\mathrm{kWh} /$ day for housing loads, where the housing load has the highest power of $2.09 \mathrm{~kW}$.

\section{E. Energy Storage}

The Homer Pro software not only considers the price of the battery, but also includes the end-of-life (EOL) cost parameter of the battery. The replacement cost parameters are shown in Table 1, with a life assumption of 25 years with a total replacement cost equal to the total investment cost of the battery. The total cost required for each BESS technology is taken from references[9]. Another parameter takes into account the capacity of the energy to be stored.

\section{RESULT AND ANALYSIS}

After assembling the system components technically and financially in the HOMER simulation, you will get the parameter Levelized Cost of Energy (LCOE) ( $\$$ / kWh). LCOE is a parameter for measuring lifetime costs divided by energy production, calculating the present value of the total capital, and operating costs of a power plant over an assumed life and allowing comparison of variation technologies (e.g., solar, wind, natural gas) of project size, capital costs differences, risk, return, and capacity[10]. 
From the simulation results, the power plant from the PV system (1 MWp) annually produced (1,450,406 kWh / year), which means that the average daily PV system generation was $(3,974 \mathrm{kWh} /$ day). If $20 \%$ of the total energy generated by the PV system per day was required to be stored, then $20 \%$ of the $(3,974 \mathrm{kWh} /$ day) battery storage system capacity was required for $794.8 \mathrm{kWh}$. In this simulation, the writer compares the use of various battery in PV on-grid system. The table below shows the LCOE parameters based on the simulation results for each technology and each battery system size.

TABLE III. BESS PARAMETER OF HOMER PRO SIMULATION

\begin{tabular}{ccccc}
\hline Name & Chemistry & $\begin{array}{c}\text { Capital } \\
\text { Cost } \\
(\$ / \mathbf{k W h})\end{array}$ & $\begin{array}{c}\text { 25 Years of } \\
\text { EOL Cost } \\
\mathbf{( \$ / k W h )}\end{array}$ & LCOE \\
\hline $\begin{array}{c}\text { UET } \\
\mathbf{5 0 0 k W}\end{array}$ & VRFB & $\$ 3,000.00$ & $\$ 3,000.00$ & $\$ 1.03$ \\
\hline $\begin{array}{c}\text { Zinc } \\
\text { Bromide }\end{array}$ & $\mathrm{ZnBr}$ & $\$ 1,675.00$ & $\$ 1,675.00$ & $\$ 1.05$ \\
\hline Li-Ion & Li-Ion & $\$ 1,800.00$ & $\$ 1,800.00$ & $\$ 1.05$ \\
\hline $\begin{array}{c}\text { Without } \\
\text { BESS }\end{array}$ & - & - & - & $\$ 2.06$ \\
\hline
\end{tabular}

\section{SIMULATION RESULT}

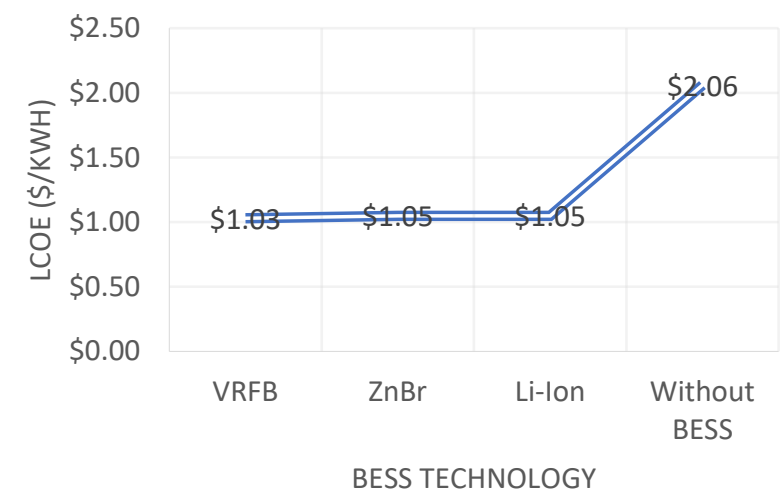

Figure 5 The Graph of Simulation Results between LCOE and BESS Technology

Three battery technologies, namely VRFB, $\mathrm{ZnBr}$, and LiIon were options for techno-economic analysis. The three battery technologies were in accordance with the capacity of the designed battery storage system, which was $794.8 \mathrm{kWh}$, and the other battery technologies shown in Table 1 could not be simulated because the battery storage capacity did not match the catalog available in the HOMER Pro software.

The graph of the simulation results shows that battery technology can minimize LCOE. When the PV on-grid system is not installed BESS, it will increase the LCOE value by $\$$ 2.06 . The difference in value is $\$ 0.51$ when compared to the $\mathrm{PV}$ on-grid where BESS is installed. If the LCOE is higher, the efficiency of the system will decrease (DOE Office of Indian Energy, 2015). LCOE $\mathrm{ZnBr}$ and Li-Ion have the same value of $\$ 1.05$, when compared to the lowest $\mathrm{LCOE}$ value of VRFB which only has a very small difference of $\$ 0.02$. Therefore, these three battery technologies are very competitive. Table 5 is a comparison between Lithium (LiIon) and Vanadium (VRFB).

TABLE IV. DIFFERENCES BETWEEN LITHIUM (LI-ION) AND VANADIUM (VRFB) [11]

\begin{tabular}{|c|c|c|}
\hline & Lithium (Li-Ion) & Vanadium (VRFB) \\
\hline $\begin{array}{l}\text { Cell } \\
\text { Design }\end{array}$ & $\begin{array}{l}\text { Stores energy in cells. } \\
\text { Some of which are } \\
\text { cylindrical and require } \\
\text { cooling space if it is } \\
\text { implemented on a grid } \\
\text { scale. }\end{array}$ & $\begin{array}{l}\text { Stores energy in the tank. } \\
\text { Electrolyte - the fluid that } \\
\text { transfers charge inside the } \\
\text { battery - flows from one } \\
\text { tank through the system } \\
\text { back to the same tank. }\end{array}$ \\
\hline Cost & $\begin{array}{l}\text { By } 2020, \text { Baird Research } \\
\text { projects that planned Tesla } \\
\text { Motors' gigafactory will be } \\
\text { able to produce an energy } \\
\text { storage system for } \$ 400 / \\
\mathrm{kWh} \text { and will sell it for } \$ \\
500 / \mathrm{kWh} \text {. }\end{array}$ & $\begin{array}{l}\text { In } 2020 \text {, the Vanadium } \\
\text { energy storage system will } \\
\text { be produced at a price of } \\
150 \$ / \mathrm{kWh}\end{array}$ \\
\hline Lifetime & $\begin{array}{l}\text { Has a limited life. } \\
\text { Performance decreases } \\
\text { over time and is affected by } \\
\text { heat. The university notes } \\
\text { that the capacity of lithium } \\
\text { ion cells can drop to a level } \\
\text { of } 50 \% \text { after } 1,200 \text { to } 1,500 \\
\text { discharges. }\end{array}$ & $\begin{array}{l}\text { Can operate longer. The } \\
\text { active ingredient is a } \\
\text { rechargeable low-cost } \\
\text { electrolyte that never wears } \\
\text { out due to the type of } \\
\text { chemical reaction involved } \\
\text { and lasts for decades. }\end{array}$ \\
\hline Markets & $\begin{array}{l}\text { Li-Ion batteries are small } \\
\text { and expensive with limited } \\
\text { life and have a dangerous } \\
\text { "thermal runawa" reaction } \\
\text { causing them to explode. }\end{array}$ & $\begin{array}{l}\text { Vanadium is built for } \\
\text { industrial size applications } \\
\text { from a few kilowatts to } \\
\text { several megawatts. There is } \\
\text { no danger of thermal } \\
\text { reaction. }\end{array}$ \\
\hline $\begin{array}{l}\text { Stability } \\
\text { Manufacture }\end{array}$ & $\begin{array}{l}\text { Tesla Motors' gigafactory } \\
\text { will double its worldwide } \\
\text { capacity to a battery worth } \\
50 \text { gigawatts and cost } \$ 5 \\
\text { billion dollars. That's a big } \\
\text { risk. It's also worth noting } \\
\text { that there is already } \\
\text { significant unused lithium } \\
\text { ion battery production } \\
\text { capacity among vendors in } \\
\text { Korea, China and Japan. }\end{array}$ & $\begin{array}{l}\text { Setting up a Vanadium } \\
\text { storage manufacturing } \\
\text { facility is simple and very } \\
\text { low cost - orders of } \\
\text { magnitude cheaper than the } \\
\text { proposed Gigafactory. The } \\
\text { production process is also } \\
\text { simple, and green for } \\
\text { enviroment. }\end{array}$ \\
\hline Efficiency & $\begin{array}{l}\text { Has a high efficiency of up } \\
\text { to } 97 \% \text {, but when operated } \\
\text { above } 40^{\circ} \mathrm{C} \text {, the charge rate } \\
\text { drops by } 25 \% \text { and the cycle } \\
\text { lifetime decreases by } 33 \% \text {. }\end{array}$ & $\begin{array}{l}\text { Fixed efficiency, } \\
\text { unaffected }\end{array}$ \\
\hline Impact & $\begin{array}{l}\text { Lithium batteries are } \\
\text { largely not recycled. Not } \\
\text { economically feasible. }\end{array}$ & $\begin{array}{l}\text { Not harmful to the } \\
\text { environment. }\end{array}$ \\
\hline
\end{tabular}

\section{CONCLUSION}

LCOE can be used as a consideration to design a grid system that utilizes BESS and RES for other renewable energy sources, in this paper using solar energy sources.

This work demonstrates a design for comparing and optimizing various BESS with large-scale renewable energy sources such as PV to assist the decision making of the required BESS capacity and can calculate the associated costs for each type of BESS Technology. The simulation results state that Vanadium (VRFB) battery technology has the lowest LCOE. Therefore, it can be used as a very competitive option compared to $\mathrm{Li}$-Ion and $\mathrm{ZnBr}$ technologies.

Especially in Indonesia, the implementation of on-grid battery energy storage system using Vanandium technology has the potential to be used in the future. Currently, Indonesia 
still uses most of the Lead Acid and Li-Ion technology in the renewable energy grid. Based on the discussion results, the techno-economic design simulation with Vanadium (VRFB) batteries have low investment costs in the future, easy to maintain, safe, and can operate longer.

\section{ACKNOWLEDGMENT}

This work was supported by PNBP Research Grant from Universitas Sebelas Maret with contract number : 260/UN27.22/HK.07.00/2021. We would like thank to Internet of Things (IoT) Laboratory Faculty of Engineering Universitas Sebelas Maret.

\section{REFERENCES}

[1] U.S. Department of Energy. (n.d.). Energy Storage: The Key to a Reliable, Clean Energy Supply. Retrieved from www.energy.gov/articles/energy-storage-key-reliable-cleanelectricity-supply

[2] REN21, T. (2018). Renewables 2018 Global Status Report.

[3] B2TKE. (2020). PLTS Bilacenge.
[4] Khasawneh, H. J., Mustafa, M. B., Al-Salaymeh, A., \& Saidan, M. (2019). Techno-Economic Evaluation of On-Grid Battery Energy Storage System in Jordan using Homer Pro. AEIT.

[5] Gür, T. M. (2018). Review of electrical energy storage technologies, materials and systems: challenges. Energy \& Environmental Science, 2696-2767.

[6] Hart , D., \& Sarkissian, A. (2016). Deployment of Grid-Scale Batteries in the United States. U.S.: U.S. Department of Energy.

[7] Electric Power Research Institute. (2010). Electrical energy storage technology options. CA: Palo ALto.

[8] Fu, R., Remo, T., \& Margolis, R. (2018). 2018 U.S. Utility-Scale PhotovoltaicsPlus-Energy Storage System Costs Benchmark. U.S.: National Renewable Energy Laboratory.

[9] Dunn, B., Kamath, H., \& Tarascon, J. M. (2011). Electrical energy storage for the grid: A battery of choices. Science, 334(6058), 928-935.

[10] DOE OFFICE OF INDIAN ENERGY. (2015). Levelized Cost of Energy (LCOE). U.S. Departement Energy.

[11] Bill Watkins. (2014, Juli 10). Lithium or Vanadium: In Energy Storage, It's No Contest. (renewableenergyworld) Retrieved Mei 10, 2020, from https://www.renewableenergyworld.com/2014/07/10/lithium-orvanadium-in-energy-storage-its-no-contest/\#gref 